\title{
Students' Perception on Medical Ethics Learning from Two Medical Faculties in Jakarta
}

\author{
Fika Ekayanti ${ }^{1, *}$ Wahyu Arifiyanti Haryoso ${ }^{1}$, Zwasta Pribadi Mahardhika $^{2}$ \\ ${ }^{1}$ Universitas Islam Negeri Syarif Hidayatullah Jakarta (UIN Jakarta) \\ ${ }^{2}$ Universitas Yarsi \\ *Corresponding author. Email: fikaekayanti@uinjkt.ac.id
}

\begin{abstract}
Background: Medical ethics is one of competencies that medical doctor' graduates should be accomplished. However, there is no consensus on standard of ethics learning for medical students. Many variations carried out by different medical faculties. This study aimed to identify the students' perception of medical ethics learning in 2 medical faculties. Method: This was a descriptive analysis study from questionnaires to final academic year students about medical ethics learning in the medical faculty of UIN Syarif Hidayatullah Jakarta (UIN) and Universitas Yarsi (Yarsi). Total sampling was used with exclusion of students who had to join his juniors. Data was collected between November 2019 to May 2020 with total respondents of 212 people (83 UIN and 129 Yarsi). Data was analysed by SPSS 20 with chi-square analysis. Result and discussion: Ethics learning in both faculty of medicine were integrated within the module. However, about $75 \%$ UIN students said the medical ethics learning was done in each semester, while only $52 \%$ Yarsi students agreed ( $\mathrm{p}=0.014) .60 \%$ of UIN students were agreed that there was always trigger case related to medical ethic, while $69 \%$ Yarsi students were agreed $(\mathrm{p}=0.012)$. There was no disagreed from Yarsi students, while 5\% of UIN students were disagreed that they were competent to handle ethics problems (0.036). Conclusion: Medical students have learned medical ethics differently among medical faculties. Self-evaluation of their medical ethics learning, and competency showed significantly different. To ensure the graduates has minimal standard for ethics competency, standard for medical ethics learning needs to be used in designing the learning process for the students.
\end{abstract}

Keywords: Bioethics, ethics competencies, ethics education.

\section{INTRODUCTION}

Ethics is systematic reflexion on, and morality analysis related to virtues, right and wrong actions, and true or false character or behaviour [1]. Ethics is a social concept from good behaviour. Beauchamp and Childress have given contribution on common morality related to principles of biomedical ethics. Those are autonomy, non-maleficence, beneficence, and justice [2]. In professional ethics, problem with dilemmatic situation would happen. The value of common morality could be stronger or weaken when the problem is seen in different stakeholders' perspectives. Medical doctors should be able to solve the problem with the best ethical decision for all stakeholders involved in it [3].

Medical ethics is related to professional identity that are influenced by the professional community, role model, reflexion on experience in medical education and the diverse conditions in medical practice. Ethics dilemma should be seen in a comprehensive point of view because it is influenced by the social, culture and religion in the community where the practice were performed [4]. Ethics should be taught to medical doctors since they were medical students as one of requirement in medical education [5].

In Indonesia, medical ethics should be included in medical curriculum since it is one of medical doctor standard of competence [6]. However, many medical faculties put more emphasis on biomedical and clinical sciences, while less attention to sociocultural determinant factors related to health, including ethics. It often created interaction issues when the students have becoming practitioner with his patients, and their family [7]. Therefore, ethics learning should be part of core curriculum that formally taught in medical education to prepare students facing complex dilemmatic problems in medical practices [8].

Today, Indonesia has about 93 medical faculties distributed in many cities of provinces. The background of each medical faculties is different. The medical curriculum is also implemented differently, depends on 
the vision and mission of the faculty. In public and general private faculties, the medical curriculum implementation is for general students, not related to their beliefs. Some of medical faculties in Indonesia have religious background universities, depend on the philosophy of how the institution was established. Due to the religious mission of Muslim Doctor production as the graduate outcome in Islamic background medical faculties, the medical ethics learning should be underlined the Islamic values as an important aspect to consider in ethical decision making. Therefore, to understand the ethics learning program from the faculties with religious background universities, this study aimed to compare the students' perception on medical ethics learning from two medical faculties with Islamic background universities in Jakarta.

\section{METHOD}

This study used a descriptive analysis study from questionnaires to final academic year students about medical ethics learning in the medical faculty of UIN Syarif Hidayatullah Jakarta (UIN) and Universitas Yarsi (Yarsi) that are located around Jakarta. Students in their last year semester $\left(7^{\text {th }}\right.$ semester) of the preclinical year were selected as students' respondents. Total sampling was used with exclusion of students who had to join his juniors. Data was collected between November 2019 to May 2020 with total respondents of 212 people (83 UIN and 129 Yarsi). Self-administered, piloted questionnaire was given to students. It consisted of 20 likert-scale questions and 2 open questions. The likert-scale questions were divided into 5 groups of questions, which were ethics learning processes, teacher representation, integration of Islamic values in medical ethics teaching, assessment, and students' perception of their accomplishment in ethics. The open questions asked about the students' understanding on definition of medical ethics and the example of ethical issues in medical practice. Data was analysed by IBM SPSS Statistics 27 for univariate analysis with frequency and distribution, and for bivariate analysis with chi-square analysis.

\section{RESULTS AND DISCUSSION}

From students' respondents, the medical students were mostly female gender. In UIN, there were 31 $(37,3 \%)$ male students and $52(62,7 \%)$ female students, while in Yarsi there were $28(21,7 \%)$ male students and $101(78,3 \%)$ female students. The range of age around 19 to 26 years old, mostly in their 23 years old in both medical faculties. From the 20 questions that were asked to the students, 7 questions about ethics learning processes, 4 questions about teacher representation, 4 questions about integration of Islamic values in medical ethics teaching, 4 questions about assessment, and 1 question about students' perception of their accomplishment in ethics.

\subsection{Ethics learning processes}

From table 1, no. 1 to 7 are related to ethics learning processes. From the 7 questions, 3 questions had significant difference, while 4 other questions had no significant difference. The results that showed significant difference were having medical ethics subject in every semester, having medical ethics learning in a specific block/module, and being taught about principle of bioethics. In UIN, 75\% students said that they had medical ethics subject in every semester, while in Yarsi, there were only $52 \%$, with $31 \%$ doubted, and $17 \%$ disagreed $(\mathrm{p}=0.014)$. In Yarsi, 89\% students said that ethics was done in a specific block, while in UIN, 77\% students said that ethics was done in a specific modul, with $15 \%$ doubted, and $8 \%$ disagreed $(p=0.0001)$. In Yarsi, 92\% students said that they were taught about principle of bioethics, while in UIN, $89 \%$ students said that they were taught about principle of bioethics $(\mathrm{p}=0.012)$.

From the curriculum, there was a longitudinal module in each semester in UIN Jakarta for Islamic Muslim Doctor and Bioethics (IMDB) which is integrated in every module for 2 hours lecture and in the PBL case. In Yarsi, the batch of the students that was selected as the respondents had the old curriculum which only has one time ethics block in the early study year. Since 2019, Yarsi has changed their curriculum for ethics also included in Personal Professional Development (PPD) model that was done longitudinally and integrated with other blocks. From the students' opinion, it showed that the curriculum design for medical ethics learning in the two faculties was differently implemented.

The other results that showed no significant difference between the two medical faculties were having medical ethics learning in every block/module, every trigger cases always discussed topic in medical ethics, being taught controversy ethical issues in the community, and being taught in variated learning methods for ethics learning. The finding was relevant to the study on University of Glasgow in 2004 that small group teaching was preferred to medical ethics learning with case discussion than in the large group teaching [9]. In other study by Rosenbaum, et al (2004) added that multiple sessions and opportunities for demonstration, reflection, discussion, practice, and feedback would be effective that conventional teaching model [10].

\subsection{Teacher representation}

From table 1, no. 8 to 11 are related to teacher representation. There was no significant difference 
among the questions about the students' perception to the teacher representation from the two medical faculties. The students said that they think it was important to have lecturer that can be their role model for medical ethics. Mostly now, they had already had their own role model teacher. In Ozan, et al (2010) study mentioned about the teacher should realize that students saw them as their role model for ethical provision of services. Teacher's role to review the interaction between their action and the students' perspective is important to shape up the ethical profession attitudes and behaviours [11]. The students mostly thought that their lecturer and facilitator/tutor had well enough knowledge on medical ethics, although 5\% UIN and 2\% Yarsi students were disagreed. Students mostly said that the lecturer and facilitator/tutor discussed about Islamic values, however, about $6 \%$ UIN students and 3\% Yarsi students disagreed that their teacher discussed Islamic values.

\subsection{Assessment}

For assessment in medical ethics learning, there were 4 questions asked to students (no. 12 to 15 in table 1). From UIN, 71\% students said the score of medical ethics assessment was included in related module, while in Yarsi students' perception, 85\% were included in the related module, while in UIN students were $71 \%, 23 \%$ doubted, and $6 \%$ disagreed $(\mathrm{p}=0.012)$. For Yarsi ethics curriculum, the students mostly agreed $(87 \%)$ that the assessment for ethics for an ethics module, while in UIN, only $72 \%$ agreed, and $10 \%$ students were disagreed $(\mathrm{p}=0.005)$. For MCQ assessment, there was also significantly different results for the students' opinion between the two medical faculties. UIN students (67\%) were less agreed than Yarsi students (82\%) to it. Some of UIN students doubted (25\%) and disagreed (8\%), while Yarsi students only $16 \%$ doubted and $2 \%$ disagreed $(\mathrm{p}=0,008)$. Last question in assessment was that medical ethics was excluded in students' assessment. Less than half students in both medical faculties were agreed that medical ethics was excluded in students' assessment, while about more than $20 \%$ students were disagreed.

\subsection{Integration of Islamic values in medical ethics teaching}

There were 4 questions from no 16 to 19 (table 1) asked about students' perception for integration of Islamic values in ethics learning. About 3 questions were significantly different between UIN and Yarsi students' perception. There was about $92 \%$ Yarsi students that felt the medical ethics has integrated with Islamic studies, $7 \%$ doubted and only $1 \%$ disagreed, while in UIN only $78 \%$ students agreed, $16 \%$ doubted, and $6 \%$ disagreed $(\mathrm{p}=0.003)$. It is also the same with trigger cases. In Yarsi, $86 \%$ students agreed that every cases always discussed the Islamic values, while in UIN, only $68 \%$ students agreed, with $26 \%$ doubted and $6 \%$ disagreed $(\mathrm{p}=0,001)$. In UIN, the students' perception about Islamic medical ethics was different to medical ethics in general, were mostly answered doubted (24\%) and disagreed (30\%), while $59 \%$ Yarsi students answered that Islamic medical ethics was different to medical ethics in general, $26 \%$ doubted, and only $15 \%$ disagreed that it was different $(p=0.009)$. Ethics from Islam perspective is good character, based on Qur'anic teaching and Sunnah of the prophet Muhammad. The principles of Islamic ethics are fear of Allah (taqwa), limits of Allah (hadood Allah), rights of people (haqooq ul ebad), perfection or excellence (ahsan), justice (adil), nice manners (ikhaq e husna), sincerity (ikhlas), and visit the sick (ayadat) [12]. It showed one of the difference of Islamic ethics and general ethics. In a study of Aldughaither, et al (2012) about student perspectives on a course on medical ethics in Saudi Arabia, stated that more that $60 \%$ students agreed to add fiqh (jurisprudence) issues to medical ethics learning. The reason was because Islam is a comprehensive religion and figh is a social need [13]. Fiqh issues was also the distinction for Islamic medical ethics. It also strengthened the difference of Islamic medical ethics with the general medical ethics, However, more than half of the students in UIN answered disagreed, while in Yarsi, more than half students answered agreed. This different opinion among students from the two faculties showed that there was something different in the approach of the medical ethics learning. The question about learning Islamic medical ethics in pre-clinical year was no significant difference. Both medical faculties have had medical ethics learning in the pre-clinical years.

\subsection{Students' perception of their accomplishment in ethics}

The question about students' perception was only one question that was about students' opinion for their competency to solve medical ethics problems. There were $72 \%$ UIN and $74 \%$ Yarsi students felt that they are capable enough to solve medical ethics problems that they would face in their practice. There are still about $23 \%$ UIN and $26 \%$ Yarsi students doubted that they were competence enough, while in UIN, there was $5 \%$ students felt incompetence to deal with medical ethics cases.

The two open questions that were asked to the students regarding the students' understanding of medical ethics from two universities and medical ethics issues from students' perception. Most of students understanding of medical ethics was that ethics is a behaviour, so ethics is a guideline for how doctors should behave. Others stated that ethics is a picture of how a doctor should do his job as a professional. Only some argued that ethics is a morality. Apart from that, 
respondents think that ethics is an attitude and obligation, or morals and norms that a doctor must carry out. From the students' perception in the two medical faculties, different understanding of medical ethics was significant $(\mathrm{p}=0.004)$. In UIN, students understanding was more to professionalism, while in Yarsi was more to attitudes (Table 2).

The medical ethics issues from students' perception were mostly selected non maleficence as the highest medical issues and it was the same in the two medical faculties ( $p=0.106)$. In Jotkowitz, et al (2017), actually the main factor of dispute in ethics dilemma was related to autonomy. It was also the main conflict between modern bioethics and religion [14]. In Iran, Alni, et al (2018) had identified that respect to patients' values is one of the important ethics topics for the students achieved [15]. There was little data on the students' perception about medical ethics in Indonesia. Medical faculties should be given more attention to medical ethics learning in medical education.

\section{CONCLUSION}

Medical students have learned medical ethics differently among the two medical faculties. Selfevaluation of their medical ethics learning, and competency showed significantly different. The process of learning, the teachers, the integration to religious affairs, and the assessment has showed a significant difference in some points. Those difference should be minimized to ensure the minimal standard of medical ethics competency has been achieved by the graduates. Therefore, minimal standard for medical ethics learning needs to be made as a reference in designing the ethics learning for the students. The faculties also need to improve their attention for medical ethics learning since it is one of the competence of medical doctors.

\section{AUTHORS' CONTRIBUTIONS}

Fika Ekayanti is the principal and corresponding researcher. Wahyu Arifiyanti Haryoso is research assistance, and Zwasta Pribadi Mahardika is technical collaborator from Universitas Yarsi.

\section{ACKNOWLEDGMENTS}

We thank to UIN Syarif Hidayatullah Jakarta that has supported the publication of the study and to Universitas Yarsi that has agreed to join this study.

\section{REFERENCES}

[1] J.L. Spitz, Chapter 48: Clinical ethics for obstetric sonography in: Textbook of Diagnostic Sonography, ed. Sandra Hagen-Ansert, Elsevier, St. Louis, 2018, pp. 1171-1176.
[2] T. Beauchamp, J. Childress, Principles of Biomedical Ethics, 7th edition. Oxford University Press, New York, 2013.

[3] M. Christen, C. Ineichen, C. Tanner, How "moral" are the principles of biomedical ethics? - a crossdomain evaluation if the common morality hypothesis, BMC Medical Ethics, vol. 15:47, 2014, pp 1-12. DOI: https://doi.org/10.1186/1472-6939$\underline{15-47}$

[4] R. Chadwick, D. Wilson, The Emergence and Development of Bioethics in the UK, Medical Law Review, vol 26:2, 2018, pp. 183-201.

[5] World Federation for Medical Education (WFME), Basic Medical Education: WFME Global Standards for Quality Improvement, the 2020 revision, 2020.

[6] Indonesian Medical Council. Indonesian Medical Council Decree No 21A/KKI/KEP/IX/2006 about Indonesian Medical Doctor Standard of Competence, Jakarta, 2006.

[7] P. Gupta, Humanity in medicine, J Med Ethics Hist Med, vol 4:3, 2011.

[8] M.I. Anwar, The Muslim Doctor: Guide for Ethical \& Professional Behavior, Pakistan, 2018, p.7.

[9] J. Goldie, L. Schwartz, A. McConnachie, J.Morrison, The impact of modern medical curriculum on students' proposed behaviour on meeting ethical dilemmas, Medical Education, vol. 38, 2004, pp. 942-949.

[10] M.E. Rosenbaum, K.J. Ferguson, J.G. Lobas, Teaching medical students and residents skills for delivering bad news: A review of strategies, Acad Med, vol. 79, 2004, pp. 107-117.

[11] S Ozan, S Timbil, S Semin, B Musal, Interns' perceptions on medical ethics education and ethical issues at the Dokuz Eylul University School of Medicine in Turkey, Education for Health, vol. 23:3, 2010, pp. 1-11.

[12] I. Anwar. Chapter 4. Islamic principles of ethics; The Muslim Doctor: Guide for ethical and professional behavior. 2018, pp 22-33.

[13] S.K. Aldughaither, M.A. Almazyiad, S.A. Alsultan, A.O. Al Masaud, A.R.S. Alddakkan, B.M. Alyahya, H.A. Alhassan, R.S. Albalawi, R.A. Alammar, M.S. Abaalkhail, J.S. Aljarallah, Student perspectives on a course on medical ethics in Saudi Arabia, Journal of Taibah University Medical Sciences, vol. 7:2, 2012, pp, 113-117.

[13] A.B. Jotkowitz, R. Agbaria, S.M. Glick, Medical ethics in Israel-bridging religious and secular values, Lancet, vol. 389, 2017, pp.2584-2586. 
[14] J.R. Alni, F. Borhani, A. Ebadi, S. Bazmi, Professional ethical competence for medical students: a qualitative study, Electron J Gen Med, vol 15:3, 2018, pp.1-7. DOI: https://doi.org/10.29333/ejgm/85497 
TABLE 1. Students' perception on ethics learning

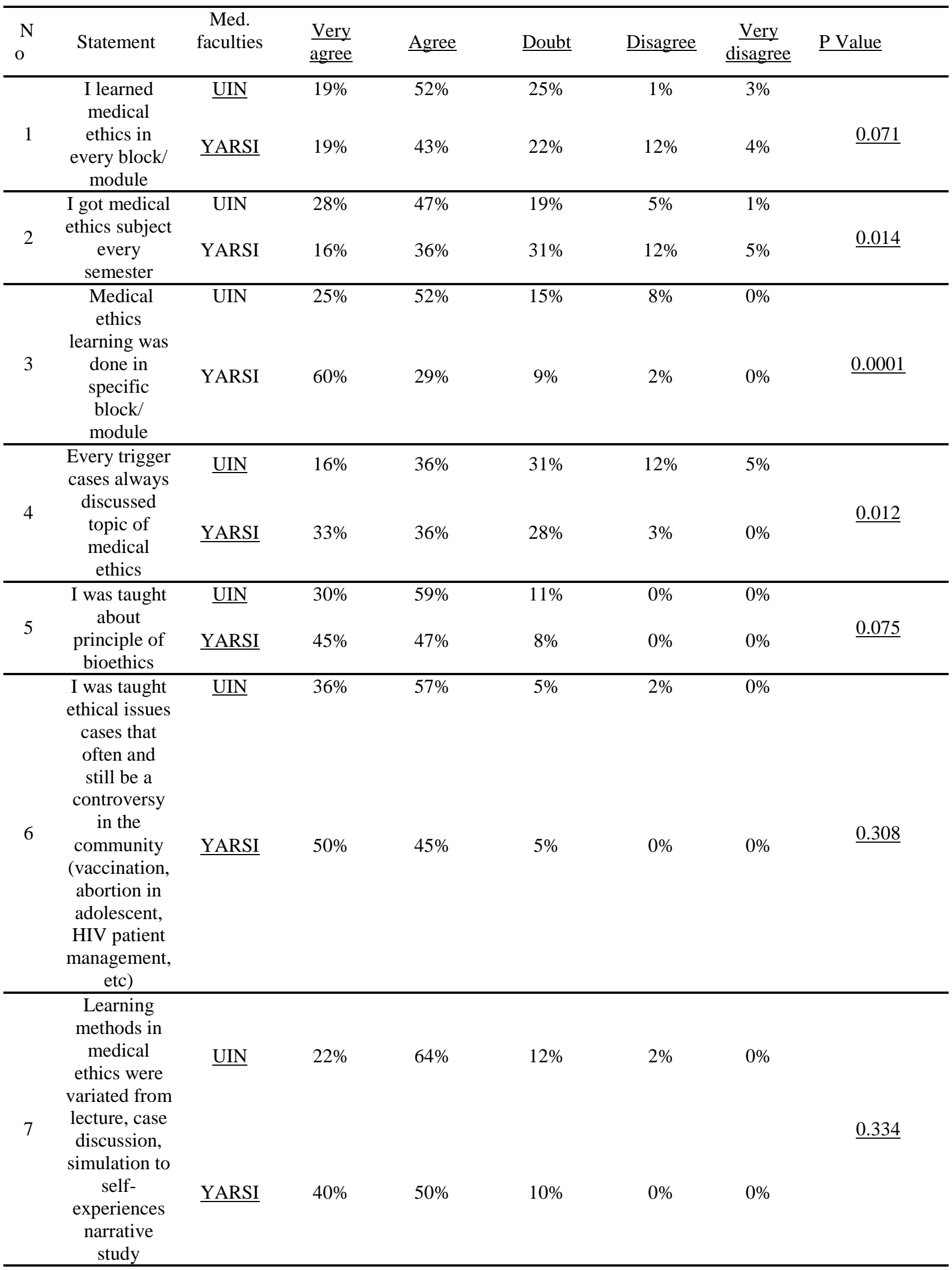




\begin{tabular}{|c|c|c|c|c|c|c|c|c|}
\hline 8 & $\begin{array}{c}\text { I think it was } \\
\text { important to } \\
\text { have a } \\
\text { lecturer who } \\
\text { has good } \\
\text { medical } \\
\text { ethics as a } \\
\text { role model }\end{array}$ & $\underline{\text { YARSI }}$ & $48 \%$ & $43 \%$ & $9 \%$ & $0 \%$ & $0 \%$ & $\underline{0.681}$ \\
\hline 9 & $\begin{array}{c}\text { I have a } \\
\text { lecturer who } \\
\text { was a role } \\
\text { model of } \\
\text { medical } \\
\text { ethics in my } \\
\text { faculty } \\
\end{array}$ & $\underline{\text { YARSI }}$ & $38 \%$ & $53 \%$ & $\begin{array}{l}7 \% \\
10 \%\end{array}$ & $1 \%$ & $1 \%$ & $\underline{0.917}$ \\
\hline 10 & $\begin{array}{l}\text { Lecturer and } \\
\text { facilitator/ } \\
\text { tutor had } \\
\text { well enough } \\
\text { medical } \\
\text { ethics } \\
\text { knowledge }\end{array}$ & $\underline{\text { YARSI }}$ & $22 \%$ & $55 \%$ & $18 \%$ & $4 \%$ & $1 \%$ & $\underline{0.230}$ \\
\hline 11 & $\begin{array}{c}\text { Lecturer and } \\
\text { facilitator/ } \\
\text { tutor also } \\
\text { discussed } \\
\text { about the } \\
\text { Islamic } \\
\text { values } \\
\end{array}$ & $\underline{\text { YARSI }}$ & $52 \%$ & $38 \%$ & $10 \%$ & $0 \%$ & $0 \%$ & $\underline{0.476}$ \\
\hline 12 & $\begin{array}{c}\text { Medical } \\
\text { ethics was } \\
\text { assessed and } \\
\text { the score was } \\
\text { included in } \\
\text { the related } \\
\text { module } \\
\end{array}$ & $\underline{\text { YARSI }}$ & $18 \%$ & $53 \%$ & $23 \%$ & $2 \%$ & $1 \%$ & $\underline{0.012}$ \\
\hline 13 & $\begin{array}{c}\text { Medical } \\
\text { ethics was } \\
\text { assessed and } \\
\text { the score as } \\
\text { an ethics } \\
\text { module }\end{array}$ & $\underline{\text { YARSI }}$ & $19 \%$ & $53 \%$ & $18 \%$ & $9 \%$ & $1 \%$ & $\underline{0.005}$ \\
\hline 14 & $\begin{array}{c}\text { Medical } \\
\text { ethics } \\
\text { questions } \\
\text { were } \\
\text { included in } \\
\text { MCQ test } \\
\end{array}$ & $\underline{\text { YARSI }}$ & $20 \%$ & $47 \%$ & $25 \%$ & $7 \%$ & $1 \%$ & $\underline{0.008}$ \\
\hline 15 & $\begin{array}{l}\text { Medical } \\
\text { ethics was } \\
\text { excluded in } \\
\text { students' } \\
\text { assessment } \\
\end{array}$ & $\underline{\text { YARSI }}$ & $14 \%$ & $33 \%$ & $33 \%$ & $18 \%$ & $6 \%$ & $\underline{0.319}$ \\
\hline 16 & $\begin{array}{c}\text { I learned } \\
\text { Islamic } \\
\text { medical } \\
\text { ethics in pre- } \\
\text { clinical year }\end{array}$ & $\underline{\text { YARSI }}$ & $51 \%$ & $38 \%$ & $9 \%$ & $4 \%$ & $0 \%$ & $\underline{0.476}$ \\
\hline 17 & & $\underline{\text { UIN }}$ & $25 \%$ & $53 \%$ & $16 \%$ & $6 \%$ & $0 \%$ & $\underline{0.003}$ \\
\hline
\end{tabular}




\begin{tabular}{|c|c|c|c|c|c|c|c|c|}
\hline & $\begin{array}{c}\text { Medical } \\
\text { ethics was } \\
\text { learned } \\
\text { integrated } \\
\text { with Islamic } \\
\text { studies } \\
\end{array}$ & $\underline{\text { YARSI }}$ & $63 \%$ & $29 \%$ & $7 \%$ & $1 \%$ & $0 \%$ & \\
\hline & $\begin{array}{l}\text { Every trigger } \\
\text { cases always }\end{array}$ & $\underline{\text { UIN }}$ & $22 \%$ & $46 \%$ & $26 \%$ & $6 \%$ & $0 \%$ & \\
\hline 18 & $\begin{array}{l}\text { discussed the } \\
\text { Islamic } \\
\text { values }\end{array}$ & $\underline{\text { YARSI }}$ & $49 \%$ & $37 \%$ & $13 \%$ & $1 \%$ & $0 \%$ & $\underline{0.001}$ \\
\hline & $\begin{array}{l}\text { In my } \\
\text { opinion, } \\
\text { Islamic } \\
\text { medical }\end{array}$ & $\underline{\text { UIN }}$ & $10 \%$ & $36 \%$ & $24 \%$ & $25 \%$ & $5 \%$ & \\
\hline 19 & $\begin{array}{l}\text { ethics was } \\
\text { different to } \\
\text { medical } \\
\text { ethics in } \\
\text { general }\end{array}$ & $\underline{\text { YARSI }}$ & $23 \%$ & $36 \%$ & $26 \%$ & $10 \%$ & $5 \%$ & $\underline{0.009}$ \\
\hline \multirow{4}{*}{20} & \multirow{4}{*}{$\begin{array}{l}\text { My medical } \\
\text { ethics } \\
\text { learning has } \\
\text { given me } \\
\text { enough } \\
\text { competency } \\
\text { to solve } \\
\text { medical } \\
\text { ethics } \\
\text { problem }\end{array}$} & \multirow{3}{*}{$\underline{\text { UIN }}$} & \multirow{3}{*}{$13 \%$} & \multirow{3}{*}{$59 \%$} & \multirow{3}{*}{$23 \%$} & \multirow{3}{*}{$4 \%$} & \multirow{3}{*}{$1 \%$} & \multirow{4}{*}{$\underline{0.828}$} \\
\hline & & & & & & & & \\
\hline & & & & & & & & \\
\hline & & $\underline{\text { YARSI }}$ & $24 \%$ & $50 \%$ & $26 \%$ & $0 \%$ & $0 \%$ & \\
\hline
\end{tabular}

TABLE 2. Understanding medical ethics

\begin{tabular}{lccccc}
\hline & \multicolumn{2}{c}{$\underline{\text { UIN }}$} & \multicolumn{2}{c}{$\underline{\text { YARSI }}$} & $\underline{\text { P Value }}$ \\
& $\frac{\text { Respondent }}{\underline{\mathrm{s}}}$ & $\underline{\%}$ & $\frac{\text { Respondent }}{\underline{\mathrm{s}}}$ & $\underline{\%}$ & \\
Manner & 4 & $5 \%$ & 11 & $9 \%$ & \\
Obligation & 6 & $7 \%$ & 11 & $9 \%$ & \\
Moral & 5 & $6 \%$ & 8 & $6 \%$ & \\
Attitude & 19 & $23 \%$ & 47 & $36 \%$ & $\underline{0,004}$ \\
Norm & 8 & $10 \%$ & 12 & $9 \%$ & \\
Professionalism & 24 & $29 \%$ & 9 & $7 \%$ & \\
Virtues & 8 & $10 \%$ & 11 & $9 \%$ & \\
Others & 9 & $11 \%$ & 20 & $16 \%$ &
\end{tabular}


TABLE 3. Ethics Medical Issues According to Respondents

\begin{tabular}{lccccc}
\hline & \multicolumn{2}{c}{$\underline{\mathrm{UIN}}$} & \multicolumn{2}{c}{$\underline{\text { YARSI }}$} & \\
& Respondents & $\underline{\%}$ & Respondents & $\underline{\%}$ & $\underline{\text { P Value }}$ \\
Beneficent & 6 & $7 \%$ & 10 & $8 \%$ & \\
Non maleficence & 23 & $28 \%$ & 38 & $29 \%$ & \\
Justice & 3 & $4 \%$ & 10 & $8 \%$ & 0,106 \\
Autonomy & 18 & $22 \%$ & 32 & $25 \%$ & \\
Ethics Dilemma & 5 & $6 \%$ & 16 & $12 \%$ & \\
Others & 28 & $34 \%$ & 23 & $18 \%$ &
\end{tabular}

